\title{
Science and Human Nature: A Complex Dynamics of Reality
}

\author{
Barrister Samuel Asuquo Ekanem, Ph.D \\ Department of Educational Foundations and Administration, \\ Faculty of Education, \\ Cross River University of Technology \\ Calabar - Nigeria
}

\section{Doi:10.5901/mjss.2013.v4n2p389}

\section{Abstract}

Man is a complex being that has defied all efforts to comprehend. This complexity is basically due to the nature of man. Several scholars and philosophers right from the ancient epoch to the contemporary period have employed several methods toward the understanding of man, but without any satisfying result. This effort to understand the nature of man has generated several problems that transcend philosophy into the sciences. Also, the scientific approach to grasp the nature of man has not yielded concrete evidence of satisfaction. This again, is due to the nature of science, which empirical orientation and root cannot capture the whole essence or nature of man which transcends the physical. This therefore, has created epistemological vacuum that has made it difficult for man to understand himself or reality that he constitutes. This scenario has created confusion in the search towards the understanding of man thereby revealing the dynamic nature of reality which includes man. This paper, therefore, seeks to explain human nature and the nature of science and posits that man or reality cannot be understood using a singular method of science but rather a combination of what the paper describes as a philo-scientific approach.

\section{Introduction}

Man as a Being is a complex issue of discourse. This complexity has made it rather difficult for human nature to be made totally comprehensible. As a result of this, human nature has posed great questions and challenges within the realm of philosophy and science. These questions and challenges tend to penetrate the entire spectrum of knowledge, thereby making the search for the understanding of human nature to be multi-dimensional and inter-connected. So, the complexity of human nature presents us with diverse pathways towards it.

Therefore, over the course of human history, people have developed several interconnected and validated ideas about human nature. These ideas have enabled successive generations to achieve an increasingly comprehensive and reliable understanding of human species and its environment. The means adopted to develop these ideas are particular ways of thinking, observing, experimenting and validating. These ways represent a fundamental aspect of the nature of philosophy and science and reflect how human nature tends to be diverse.

It is through the union of science and philosophy that the understanding of human nature would be made possible. Although each of these human enterprises or activities has a character and history of its own, each is dependent on and reinforces the other. Accordingly, it is through the philo-scientific approach that human nature can be understood.

Science presumes that the things and events in the universe occur in consistent patterns that are comprehensible through careful, systematic study. It is the belief in science that through the use of the intellect, and with aid of instruments that extend the senses, people can discover patterns in nature.

Also, science assumes that the universe is, as its name implies, a vast single system in which the fundamental rules are all the same. Therefore, knowledge gained from studying one part of the universe is applicable to all other parts. This can be seen in the principles of motion and gravitation that explain the motion of falling objects on the surface of the earth, which equally explain the motion of the moon and the planets. With certain modifications over the years, these same principles of motion have applied to other forces, and to the motion of everything.

Despite this, science cannot provide complete answers to all questions that include human nature. There are indeed many matters that cannot be meaningfully examined in a scientific way. There are, for instance, beliefs that by their nature cannot be proved or disproved as can be seen in the existence of supernatural powers and beings, or the true or real purpose of life. Also, there cannot be a valid scientific approach to the explanation of miracles, fortune-telling, 
astrology and superstition. Again, scientists have no apparatus to settle issues about good and evil and the identification of the nature of human mind, which is the seat of human consciousness.

It is clear from this analysis that there is an epistemological vacuum created within the scientific domain as far as human nature is concerned. This is largely due to the empirical pattern of science. Science, with its empirical tools cannot really grasp the dynamics of human nature, which is the anchor point of reality. This has brought about epistemological conflict as to what constitutes human nature. It is therefore the position of this paper that this conflict or confusion can be resolved through a philo-scientific mediation.

\section{Conceptual Analysis}

The basic concepts discoverable in this discourse are science and human nature.

\section{Science}

It is rather difficult to provide a single definition of the concept of science. This is due to the fact that science as a concept conjures several meanings to different people. However, several dictionaries see science as the means through which knowledge is arranged in an organized pattern. Again, this knowledge is derivable from experience, observation and experimentation. It is on the basis of this that scientific knowledge is seen as proven knowledge. So, within the scientific enterprise, there exist no such things like personal opinions, prejudices, superstitions and speculative imaginations (Ekanem, 2007).

This notion of science makes it rather difficult to grasp the whole of reality within the scientific module or method. This is because science is basically limited in terms of its methodology of observation and experimentation, which is anchored on experience. This puts the concept of "man" beyond the scope of scientific comprehension. Despite this, however, science is said to be a systematic and comprehensive approach or method that addresses specific types of questions and provide certain types of answers in which results are usually dynamic. This shows that the aspect(s) of reality that science can capture and understand can never be stable but ever changing.

It is therefore, on the basis of this that Uduigwomen and Maduka argue that science does not seek the supernatural explanation of our world (reality) but rather attempts "naturistic and mechanistic explanations of events in their specific domains". They further posit that science is broadly split into two, namely, "real science and formal science". In the real science, we have the natural sciences and the cultural sciences, while mathematics, structural science, the social sciences, and formal logic fall under formal science (2007).

From this, we discover that central to the real science are empiricism, objectivity and rationality. These imply that real science must essentially and necessarily be in tune with empirical data perceivable through the sensory organs or senses.

Science is also viewed as the study about the mastery of man's material environment. This implies that science involves the application of scientific knowledge and principles with cogent effort to provide solutions to man's environmental problems. This definition is seriously limited because it is just the identification of science with material results and excludes the non-material (spiritual) components of man and the world (Ladgmen, 2002).

Also, science has been defined as a systematic process of trying to discover the truth about nature with the aid of logical inference based on empirical observations and testing. This inductive process introduces some metaphysical element into the realm of science, which could make it possible for science to penetrate human nature that transcends the physical. In this paper, therefore, science will be taken to mean the sensory process of epistemological comprehension of nature towards the discovery of objective principles that aid man to logically interpret and domesticate his environment without dislocating the web of nature. It is the process of penetrating nature with the aim of discovering the laws that aid man to live sustainably. This is the relationship between man and his environment, which is based on careful and objective study by man to sustain the relationship. So, science involves efforts directed at discovering and understanding human nature as an essential and fundamental component of reality.

\section{Human Nature}

Human nature is a basic concept in ethics; it highlights the different conceptions of human life as can be seen in classical Greek and Christianity. Also, the enlightenment philosophy made effort to discover a constant and subsisting human nature beneath superficial differences that could be traceable to culture and society (Blackburn, 1996). 
It is a concept that holds that there is a set of inherent distinguishing characteristics, which include ways of thinking, feeling and acting. It highlights the peculiar traits inherent in man with universal characteristics or form. It deals with the causes of these distinguishing characteristics of humanity and how fixed human nature is. This has vital implications in ethics, politics and theology since these are regarded as "providing standards or norms that humans can use when judging how best to live" (Wikipedia 2010).

Human nature involves the views that there exist inherent universal human qualities. This permeates diverse intellectual activities that include metaphysics, psychology, sociology, religion, science and ethics that fall under philosophy. It is a broad epistemological notion that tends to discover the unique universal human qualities. It involves the philosophical and scientific search for the understanding of the inherent complex nature of man as a social being.

\section{Historical Trends in Human Nature}

The realization of the complexity of human nature dates back to the Ancient epoch of Greek philosophy. This can be seen in the postulations of some of the ancient philosophers like Plato, Aristotle, Heraclitus, among others. As a complex problem, the ancient philosophers could not resolve the issue or problem satisfactorily. It was therefore on the basis of this that the medieval period, characterized by scholasticism made spirited effort to reinvent and introduce Aristotelianism into its theology. This was made manifest by the postulations of Thomas Aquinas regarding what has come to be known as Christian theology.

So, the pre-modern scientific notions or understandings of nature, human nature is comprehended with reference to final and formal causes. The implication of this reveals the existence of an ideal, "concept", or "idea" or "form" of a human that exists independently of individual humans. However, Charles Darwin provided a shift and laid a scientific foundation for the modern scientific arguments that humans have no fixed nature.

This position by Charles Darwin generally known as evolutionism or transformism has generated so much debates among philosophers and scientists alike. From the mid-19th century therefore, the concept of human nature has occupied a central place in the discourse of several thinkers like Francis Bacon, Rene Descartes, Hegel, Karl Marx, Nietzsche and Sartre among others introduced diverse intellectual opinions to the debate. So, what we intend to do in this section of the paper is to briefly recast and evaluate some of these prominent and influential historical trends from the ancient epoch to contemporary time.

\section{Plato}

Plato was one of the ancient Greek philosophers that borrowed so much from Socrates. His study under Socrates also influenced his concept of human nature, and it was from this that he built his metaphysics and anthropology. The soul as can be seen in the Platonic Timaeus has a rational propensity that is situated in the human head, the spirited aspect that is found in the human heart, and an appetitive beast that is located within the belly and genitals. To Plato, therefore, it was the function or duty of the "rational" element to check and tame the other two natures of the human. This notion or belief conforms with sophism that is quite parallel to the goodness attained by the demiurge at the starting point or origin of the universe.

A cursory look at Plato's metaphysics reveals a dualism between the soul and the body. This dualism as postulated by Plato has been very influential right from the ancient period to the present day. This dualism also has penetrated Christian theology deeply. This can be seen in the Gospel of John.

It could be argued also that the methodic doubt of Descartes about his classic dictum of the soul that thinks and the body that is extended is a connection tapped from the Platonic circuit. This also applies to the Kantian contrast between the noumenal and the phenomenal aspects of human nature (Ferguson, 2003).

\section{Aristotle}

Aristotle was one of the prominent students of Plato that took a rather radical position that tends to place him in opposite of what Plato represents. Accordingly, Aristotle made certain profound and fundamental postulations about human nature. To him, man is a conjugal animal and this can be seen in his NicomacheanEthics. The meaning or implication of this is that man is an animal that is born to couple at maturity and build a household and by extension in certain cases, a clan or a village that runs on patriarchal lines. This deeply and greatly explains the foundational role of man in the evolution or development of society. 
Also, to Aristotle, man is a political animal and this is contained in his politics. The implication of this is that, man is developed from complex communities or so, that is, starting from his family and clan life, with the aim of thriving in his rationality in such an outstanding manner, towards the making of laws and traditions.

Furthermore, Aristotle sees man as a mimetic animal and this is found in his Poetic. Here, Aristotle pinpoints and revalidates the importance of human reason in its clear and undiluted form. This implies that man appreciates the utilization of his imaginative energies, and not only in the making of laws.

It is evidenced that for Aristotle, reason is not just what is the most odd as far as humanity is concerned, but is simply what humans were meant to attain at their best. Indeed, Aristotle's notions or postulations about human nature are still very much relevant today but these have not been popular in modern period (Aristotle, 1887).

\section{Rousseau}

Jean Jacques Rousseau is one of the social contractarians and his idea of human nature reflects this. Though he wrote before the French Revolution and Charles Darwin, his postulations on human nature, which are contained in his Second Discourse was a rude shock to Western Civilization. He posits the natural freedom of human beings at birth. This freedom, according to him, is innate, inalienable and basic. He proposed also that humans had once been solitary animals and had learnt how to be political. The import of this assertion is that it kicked against fixism, which is the position that human nature is fixed. This was against the position previously held and canvassed by philosophers. Indeed, humans are political, and rational and now have language, but this was originally not the case. Humans originally have none of these attributes (Ncha, 2008).

Rousseau presented himself as a student of nature, and so never denied the existence of human nature, but this was defined in terms of the instinctive passions of the original, irrational and moral human, which is linked with self preservation. This Rousseauian conception of human nature has been viewed as the fertile land that led to the planting and germination of shocking political developments of the $19^{\text {th }}$ and $20^{\text {th }}$ centuries like totalitarianism and brain washing (Delaney, 2006).

Indeed, Rousseau was a vital influence on Immanuel Kant, Hegel, and Karl Marx but as a person, he accepted the fact that he was inspired by the thought of Thomas Hobbes.

\section{Karl Marx}

There has been misconception about Karl Marx's notion of human nature. It is a general belief that Karl Marx denied the existence of human nature but that human beings are just a blank slate, whose character will be dependent wholly on their socialization and experience. This Marxian conception tallies with the "tabula rasa" postulation of John Locke of the human mind. It is evidently clear that Marx had so much confidence in the view that humans are mostly influenced and partially determined and shaped by their environments, rather than their material existential conditions.

Despite this, it is a fact that at a particular stage of his development, he had a virile view about human nature. During this time, Marx discussed the concept of "species-essence", which is taken from the German "Gattungswesen", and usually translated as "species being". He holds that under capitalism, human beings are alienated, that is, completely separated or different from aspects of human nature. He envisioned the possibility of a society following capitalism that would permit human beings to fully exercise their human nature and individuality. He provided the name "communism" for this "imagined" society. There has been divergence of usage that is far from the original meaning that Marx intended.

The understanding of Marx about human nature did not only influence or play a role in his critique of capitalism but also his belief in the emergence of a better society as already pointed out, it equally influenced his theory of history. The fundamental dynamic of history, according to Marx, is the expansion of the productive forces. Marx through The German Ideology asserts that the two or the three aspects of social activity that ground history are the tendency of humans to act with the aim to fulfill their needs, and thereafter, the ability or capacity to bring about new needs. This is anchored on the dialectic principles, as this human capacity according to Marx, is the oil that lubricates the wheel of the continuing expansion of the productive power in human civilization.

We have not been able to discover the term "species-essence" outside The German Ideology in all the writings of Karl Marx. However, most of the major translators of Marx like Louis Althusser, argued that "species-essence" is very irrelevant to Marx's later writings, but others like Terry Eagleton and Andrew Chitty hold that it is still a vital concept in the understanding of Marx (Wikipedia, 2010). 
This paper is, however, of the view that the "specie- essence" is a vital component of Marx's philosophy as can be seen in the historical root of Marx's "historical materialism", which was tapped and inverted camera obscura from the Hegelian Absolute Spirit".

The opposition to Marxism can be seen among the thinkers of the Austrian school of economics around 1871-1940. Their views as were largely developed were in direct opposition to Marx. Thus, they were able to come up with a distinctive view of human nature though greatly influenced by earlier philosophers of the Enlightenment. Like Rene Descartes and Immanuel Kant, these thinkers held that there exists an invariant human nature but that progress can only be achieved through a more holistic understanding of that nature.

\section{Sigmund Freud's Psychoanalysis}

Within the same time, Austria also played host to the development of psychoanalysis. The founder of psychoanalysis, Sigmund Freud, held that the Marxists were right to focus on what he referred to as "the decisive influence which the economic circumstances of man have upon their intellectual, ethical and artistic attitudes". However, he posited that the Marxist view of the Class struggle was rather a too shallow one, which assigns to recent centuries conflicts that were indeed, primordial. According to Freud, behind the class struggle there is the struggle between father and son, and between a clan leader and a rebellious opposition. Accordingly, Freud brought to the fore his notion of id, ego and super ego and the desires that come with each aspect of personality.

\section{Wilson's Sociobiology}

Among the most recent contemporary works on human nature are those of Edward O. Wilson's book Consilience: The Unity of Knowledge written in 1998 and Pierre Hadot's The Veil of ISIS: An Essay on the History of the Idea of Nature, published in 2004. These books contain fundamental and central issues on human nature. However, the book that is of interest and relates to the title of this paper is that of Wilson. In his book, Wilson opined that it is time for a cooperation of all the sciences to explore human nature. He viewed human nature as a collection of epigenetic rules, that is, the genetic patterns of mental development, cultural phenomena, rituals, etc., are actually products and not part of human nature. He posits that art works are not part of human nature, but that the appreciation of art is. He argued that this art appreciation or the fear for snakes or incest taboo can be studied as the methods of reductionism. Before this time, these phenomena were actually part of psychological, sociological and anthropological investigations but Wilson's proposal is that they could come under interdisciplinary research. The idea of Wilson's assertion can be seen in David E. Jones' book titled An Instinct for Dragons.

Having been grounded in the views and trends on human nature from the ancient to the present day, it is therefore pertinent we look at the best approach to the understanding of human nature.

\section{Science and Human Nature}

It has been established through our analysis that human nature is a complex concept or issue of discourse. Historically, there has been a serious debate about human nature. This debate was ignited by Democritus atomistic philosophy. However, the debate became more complex and classic when Aristotle introduced the notion of homogeneity into what could be termed the philosophy of nature. It was at this point that the scientific and philosophical approaches to the understanding of nature were really established. However, Aristotle's approach was never scientific (in the modern usage) but teleological, which has a foundation in metaphysics, since it has to do with causality. This causal notion was to be high-jacked by later philosophers in an effort to make the understanding of nature scientific. The argument then was anchored on cause and effect.

This ancient problem was carried into the medieval era through Aquinas who tried to adopt the Aristotelian method or approach to the understanding of nature. The medieval church fathers could not really divorce this problem from their theological origin and so the problem persisted until the emergence of Rene Descartes, Immanuel Kant, and Francis Bacon of the modern time who made effort to scientifically study the nature of man. However, it was Descartes' methodic doubt that laid the foundation for the modern debate on the method of understanding human nature. But the question is, how do we study human beings scientifically? Is it possible to use the methods developed in the study of the rest of nature in the study of humans?

To be able to respond to these questions, it is imperative we understand the nature of science and the nature of man. 


\section{The Nature of Science}

Fundamentally, the various scientific disciplines are alike because of the reliance on evidence, the use of hypothesis and theories, the types of logic employed, and several other aspects. However, scientists differ greatly from one another because of the kind of phenomena they investigate and how they go about their work; the reliance they place on historical data or on quantitative methods in their recourse to fundamental principles; and in how much is drawn on the findings of other sciences.

The validity of scientific claims is usually settled by referring to observations of phenomena, hence, scientists concentrate on getting accurate data. Such evidence is obtained by observations and measurements taken in situations that range from natural settings (like a bush or a river) to completely contrived ones (like the laboratory). In making observations, scientists use their senses, instruments (like microscopes) that assist to enhance those senses, and instruments that can tap characteristics quite better, accurate and different from what humans can sense (like magnetic fields). Scientists probe the world in diverse ways.

In certain circumstances scientists control situations and conditions deliberately and precisely so as to get their evidence. This control is usually referred to as "controlled variable". This may involve the control of temperature, changing the concentration of chemicals, or choice of specimen(s). Through the variation of just one condition at a time, scientists hope to identify its exclusive effects on what happens, uncomplicated by changes in other conditions. However, in most cases, control conditions may be impractical (as can be seen in the study of the stars or the sun), or/and unethical (as can be seen in using humans as objects of experiment), or even likely to distort the natural phenomena (like we can see in wild life study whereby the animals are held captive) (Dupre, 2001).

Also, science is a blend of logic and imagination. Imagination and thought are usually used to come up with hypotheses and theories but these have to conform to the principles of logical reasoning, which is the testing of the validity of arguments through the use of certain criteria of inference, demonstration, and common sense (Ekanem, 2007).

Furthermore, scientists attempt to make sense of observations of phenomena through the construction of explanations that are consistent with generally or currently acceptable scientific principles. These explanations and theories may be sweeping or restricted, but they must be logically sound and have to incorporate a significant body of scientifically valid observations. Indeed, the essence of science is the validation of observation. It is through this that prediction is made possible in science.

Basically, our analysis reveals empiricism as the capstone of science. It is on the basis of this that the limitation of science emerge, hence, science cannot study or investigate all things and so cannot provide complete answers to all questions. This assertion can be seen in the words of Florice Tanner(1973) in the book, The MysteryTeachings in World Religions as she writes "...Consciousness of the Absolute goes beyond the limits of all the various force fields which scientists explore. A nonmaterial Reality transcends the transitory fields in which man usually thinks and lives...."

\section{Human Nature}

Human nature as a concept is a very complex one. As a result of this complexity, the discovery of human nature must first begin with the understanding of human person. It is on the basis of this that Omoregbe (1996) began his discourse on human nature by first providing a classical definition of Boethius of a person, as "an individual substance of a rational nature". The implication of this is that a person must as a matter of necessity be a rational being, or as Omoregbe (1996) puts it, "a rational substance". As a matter of fact, a rational being must possess self-consciousness or, put differently reflective consciousness. It is not just that a person must have consciousness, he must be conscious of the very fact that he is conscious. There must be that awareness of the consciousness.

It was the awareness of this consciousness that made it possible for Rene Descartes through his Methodic doubt to be conscious of the fact that he was a thinking being. This assertion tallies with the graphic presentation of Omoregbe (1996) when he wrote:

... Descartes became conscious of himself as a thinking being, his consciousness became, as it were, conscious of itself. This enabled him to affirm his existence - "cogito ergo sum" ("I think therefore I am"). Descartes might just as well have affirmed his personality. But in that case he would have had to add the fact that he knew that he was thinking. He could have said something like this: "I am thinking, and I know that I am thinking, therefore I am a person". 
From this, it is clear that one of the natural characteristics of humans is rationality. This characteristic must however, come with consciousness. So, by his very nature, the human person is a rational being, and this rationality begets morality. The implication of this is that a rational being is also a moral being. However, this does not mean that a person that is moral has to or is always doing what is morally right. The meaning of this is that humans are always subject to the moral law and so are liable to be held responsible for all their actions, whether these actions are good or bad. It follows that the human desires to be praised, blamed, punished or rewarded for his actions depending on whether such actions are morally right or wrong.

It is the realization of this fact that prompted Omoregbe in his book Metaphysics without Tears: A systematic and Historical Study to allude that;
... a person is necessarily a rational and moral being. But the concept of morality presupposes freedom. No being could be a moral being if it were not a free being. To be a moral being therefore is to be a free being. It follows that a person is not only a rational and a moral being but also a free being... (1996).

We have so far discovered three essential attributes of man and these are rationality, morality and freedom. The third attribute conforms with Rousseau's description of human nature when he says, "Man is born free and everywhere he is in chains. One thinks himself the master of others, and still remains a greater slave than they" (1913).

Following Omoregbe's submission, he argued that a baby though a human being is not a person. He says;

\begin{abstract}
A baby is, of course, a human being, but it is not yet a human person because it does not yet meet the essential requirements of personality. Although a baby has the potentiality to become a self-conscious, free and moral being eventually, as long as it remains a baby it is devoid of these essential attributes of personality. It is not yet self-conscious, makes no free decision, nor is it morally responsible for its actions. It will become a person when it shall have grown up and developed these attributes.
\end{abstract}

Indeed, Professor Omoregbe displayed a shallow knowledge of the meanings of consciousness, personality and freedom here. This is because a baby at birth has a personality of his own; possesses consciousness of his environment and makes choices. This can be seen when a baby cries, but will suddenly keep quiet when carried by his mother or father. We have also seen a baby that refused to suck the mother's breast when the mother mistakes his cries for starvation. All these go to prove that a baby is conscious, rational, and free and can make choices. Again, life according to scientific proof begins at conception. To be alive is to be conscious

What the baby may be said to be lacking is a formal language to communicate his feelings and thoughts about his environment and those he relates with. However, a baby displays appreciation and communicates through smiles, cries, and withdrawals. And language is one of the characteristics of man. Man uses language because he is a rational, thinking being. Both Aristotle and Aquinas rightly consented to this fact when they argued that language presupposes society because it is only in a society that language is used and learnt. Therefore, language is a medium of social interaction and this is what makes a man, a social being.

Professor Omoregbe consents to this fact when he says that "... man, a language-using being, is also a social being (since it is only in a society that he can use language)". So, it is very wrong to say that a baby is not a person because it lacks consciousness of using language. To accept this will also imply that a baby is not human, and this will also include the deaf and dumb who cannot talk but uses sign language, which the baby does.

Having stated this, we can therefore add that man is a social being because of his use of language for interpersonal relationship. This by extension adds to the Platonic fact that man is a political animal, which also means an animal that socializes and seek to dominate, control and dictate.

Also, man is essentially, according to Descartes, a thinking substance whose basic characteristic is thought. Although man has a body, but some philosophers do not see this as part of his nature. For Descartes, therefore, man is fundamentally a mind that happens to have a body. "Mind is characterized by thought while body is characterized by extension. The mind is an immaterial substance while the body is a material substance" (Omoregbe, 2001).

A critical look at the above explanation shows that man is basically dual in nature, and that is, the physical and the spiritual. So, it is very wrong to deny man of his body as not being a part of his nature. Following this therefore, we can say that human nature basically and broadly comprises of the physical and the spiritual. Other features, attributes or characteristics of man like being rational, moral, free, social and capable of interpersonal relationship could be classified as the metaphysical dimension or nature of man. 
Having explained or related the nature of science and human nature, the most fundamental question therefore is; can we study or understand human beings scientifically?

The position of this paper is that human beings cannot be studied or understood wholly through scientific method. To attempt using the principles and methods of science in understanding human nature will surely lead to reductionism and mechanism. Science cannot provide all the answers about human nature.

\section{The Problem of Scientific Method and Approach}

Observation, according to Ekanem (2007), is the defining module of a scientific method in any subject that is under investigation and experimentation. Observation as a process or method of science involves perception and cognitive characteristics. The implication of this is that one cannot make an observation in a passive manner, but rather, one must necessarily be actively involved in differentiating the thing that is being observed from surrounding sensory data. As a result of this, Sapir-Whorf argues as quoted by Ekanem (2005), maintains that observations depend on some underlying understanding of the way the world functions. This understanding greatly influences what is perceived or considered to be worthy of consideration.

Also, observation that is empirically carried out, is usually used to determine the acceptability or otherwise of some hypotheses within a theory. Whenever a claim of observation is made, it is proper to demand a justification of such claim. And in providing such justifications, reference must as a matter of fact, be made to the theory's operational definitions and hypotheses on which the observation is embedded. It follows then that observation is a component of the theory that also contains the hypothesis that it verifies or falsifies. The understanding here is that observation cannot be taken as a neutral or impartial arbiter between hypotheses that compete.

From this, it is clear that human beings cannot be empirically observed holistically. This is because there are fundamental aspects of human nature that cannot be observed within the power of sensory data. Again, there are no theories that generally explain human nature. So, applying the principle or method of observation will create problems and limitations.

Empiricism is the anchor point of the scientific enterprise. It is a major and fundamental concept in science. It is the root of reliability of evidence in any scientific endavour. As an epistemological or philosophical idea, it is the notion that knowledge is basically derivable from sense experience. Viewed from this perspective, scientific statements become subject to, and are derivation of our experiences or observations.

This approach or method cannot be successfully employed in understanding humans that are very complex. Again, humans are not just material or physical entities that could be mechanically controlled. Indeed, humans represent a complex network of realities that are ever dynamic. The unstable nature of humans makes them a confusing reality of sort. This is because a human is not just himself, but a totality of nature that represents reality. Man, indeed, determines what nature is, just as he is part of nature. This constitutes reality, which is confusing from the empirical standpoint. This therefore, makes it difficult for science to unravel the complex network of human nature. Reality cannot be approached from a single standpoint.

\section{The Philo-Scientific Method: A Proposal}

It is clear from our analysis so far that any attempt to adopt the methods of science will greatly distort our understanding of human nature. This fact is anchored on the idea that humans are not law-governed machines that operate or function with the touch of a button. Indeed, there exists in human nature a wide variety of phenomena related in diverse and complicated patterns or ways, at every level of the hierarchy are distinctive causal powers that do not depend on behaviour of lower-level-entities. This can be seen in the Cartesian effort to explain the relationship between the mind and the body. His choice of the "pineal gland" that is situated in the middle of the brain was abandoned by his followers such as Geulinex and Malebranche, who settled for God as the influence and cause of the body movement (Omoregbe, 1996).

Scientific approach to the study of human nature will amount to the adoption of the mechanistic view of the world, which was first made known in Western philosophy through the atomism of Democritus that rules out teleology. This will presuppose the following:

- That there is only one basic stuff out of which all material objects are made;

- That this stuff has only one intrinsic character apart from its purely spacio-temporal and causal attributes;

- That there is only one basic kind of change, which changes in the relative positions of the particles of this stuff; 
- That there is only one basic law according to which one particle of this stuff affects the changes of another particle (Broad, 1925; Omoregbe 1996).

To Broad, pure mechanism cannot adequately explain the world of our experience. This also applies to human nature. The truth is that the external or physical human nature as perceived by us cannot have the kind of homogeneity demanded by mechanism, which is scientific. The organism of the human body reveals evidence of a careful design, and so it will be more difficult to key into the mechanistic view point which is unipolar.

Human nature is more complex to be grasped from a single perspective of the scientific. It requires a combination of philosophical and scientific methods to understand man in his true nature. The broad aspect of man which is the spiritual dimension or nature that includes his being rational, moral and free can better be understood through philosophical methods. Here, the rational aspect of man can be better comprehended through epistemology; the moral and freedom aspect can be appreciated through ethics, while his conscious (mind) and creative nature can be studied through metaphysics and aesthetics. Also, the physical aspect of man that includes his having a body, being social, political and capable of interpersonal relationship can be understood through scientific methods. This is because the human body can be studied scientifically through scientific processes of biology, physiology, Anatomy and medicine. The social, interpersonal relationship and political nature of man can be unraveled through sociology, psychology, political science and law.

It is in realization of this dual approach to the study of human nature that prompted Professor Ozumba to come up with the book Philosophy and Method of Integrative Humanism. In this book, Ozumba explained that humanity and nature cannot be understood through a single method of science or philosophy. He therefore proposed an integrative approach or method which he called "integrative humanism". He says:

Having seen that every philosophical theory lacks the capacity for comprehensive application to philosophical problems, it becomes only philosophically needful and expedient to think out a method and a way by which the benefits of different theories can be harnessed and deployed for the explication of philosophic tangles and the expansion of the frontiers of our cognitive landscape-with a view to attaining comprehensive or better knowledge on issues that affect man and his World (2010).

He buttressed this view further through an epistemological analogy of "monolithic integrative circuit and a multiversity of integrated circuits", which he posits is the technology that led to microprocessors, which could perform vast and varied functions. He declares:

It is a truism that in many areas of application, the performance of integrated circuitry is far superior to that of conventional circuits. But it is worthy of note that integrated circuits, because of their small size, low power requirements and heat generation, modest cost, reliability and speed of operations, they make possible electronic system that would otherwise be impossible or rather impractical (2010).

This electronic analogy that has been introduced into philosophical discourse, explains the relevance of our philoscientific proposal as a method that could enhance our understanding of human nature. The objective of the integrative humanism as outlined by Professor Ozumba tallies with the aim of the present philo-scientific proposal. This is so because, this proposal will make it possible for the physical and spiritual aspects of man to be wholly captured and analyzed by man. This can be seen in the words of Ozumba when he writes "The undergirding objective of integrative humanism is the need to place man's physical and spiritual wellbeing at the centre of every intellectual endavour. Man's intellect seems to be skewed towards the development of material resources rather than human resources. There is the receding interest in catering to the real interests of human beings" (2010).

It is this misdirected human intellectual interest on material development that prompted Ekanem (2005) to advocate for "Essencism" as a philosophy of Education that could help promote technological development in Nigeria. In his work "A Philosophy of Education for Technological Development in Nigeria" he writes:

This new philosophy as a proposal, seeks to evolve and design a national focus, which is reflective of the real nature of man as a dual being. This dualism is clearly expressed in the mind - body interactional principle...

Essencism as a philosophy of education seeks to justify the divine importance of education. This is because, the dualistic nature of man is nobly catered for through the spiritual and physical dimensions. This philosophy attempts to place and project man as the central object of education, science and technology. It postulates that any development of the society through technology must be viewed as advancing the course 
of man. It seeks to create the much-desired harmony in man, which hitherto has been very elusive. This was because there was a collapse of the cherished channel that links man and his creator. This will help to re-open the spiritual link for man to tap the abundant potentials of this aspect for his full manifestation as an effective and functional member of the society (2005).

The value of the above advocacy is hinged on the fact that philosophy is a unified science, because there is no science without a philosophy. Hence, philosophy is taken to be a scientific enterprise that attempts the discovery of ultimate reality through a systematized process of logic, analysis, explanation and criticism which is anchored on speculative inquiry into nature and human activities. So, philosophy is the concrete foundation of human knowledge that aids man's comprehension of the universe and his nature.

Science in its empirical form or pattern cannot achieve the goal of comprehending the universe and human nature in their entirety. The reason for this is that, you cannot isolate man from his environment and nature. Man is intrinsically part of nature and constitutes the core of reality. So, any effort to study or understand man in piece-meal or fragmentally will be a fruitless intellectual exercise and will create a series of confusing dynamics of reality as buried in nature. So, the most rewarding approach to overcome this problem is through philo-scientific method. It is in line with this thinking that Omoregbe declares thus:

...civil society with all its complexity is a mirror reflecting human nature with its multiple needs. Human nature is therefore the foundation of human civil society. But it is also the foundation of human knowledge with all its ramifications. For every branch of knowledge is in some way related to man and is intended to cater for some aspects of the needs of his complex nature. All the various branches of knowledge, with their multiple areas of specialization arose as answers to some questions posed by some aspects of human nature or as solutions to some of its problems (2000).

This view must have inspired Ozumba's "Integrative humanism" as he defines it as:

... a ratio-spirito-centric approach in understanding human existence, interpreting human affairs, and a rigorous philosophical attitude which takes into consideration, the spiritual and the mundane dimensions of human existence and reality. It attempts at philosophizing from the point of view of holistic truth bearing in mind that man is both mortal and immortal, terrestrial and preternatural, spirit and body .... (2010).

These views of Omoregbe and Ozumba are all discovered in "Essiencism" as a philosophy by Ekanem when he says that "Philosophy of Essencism seeks to develop a complete human personality. This is because no aspect of the human nature or aspect is ignored. Man is totally developed as a physical and as a spiritual being through essencism" (2005). This affirms the fact that science alone cannot capture or explain the nature or essence of man.

\section{Recommendations and Conclusion}

It is a fact that science with its reliance on empiricism, observation and evidence cannot unravel the mystery of human nature. The reason for this is because, scientific method is limited in scope and is mechanistic in its application. Science can only study to some extent the physical aspect of human nature. So, to overcome this limitation of science, it is important that fundamental steps be taken to broaden the scope of the scientific enterprise through the following.

- Science must embrace metaphysics which is a fundamental aspect of nature and human.

- The knotty issue of mind which science has completely refused to investigate should be brought into the scientific enterprise.

- $\quad$ Science must strive to be speculative and imaginative.

- There must be a consistent effort to introduce the spirit of curiosity into the scientists. Scientists must be curious about the unobserved aspects of phenomena.

- The concept of spirit (immaterial substance) must necessarily be brought into the focus of science.

- With this adjustment within the scientific enterprise, philosophy which is more embracing will systematically become part of science. This will challenge the status quo of science and make it more open to penetrate the intricate web of human nature. With this approach, dogmatism which is the hallmark of science will be removed as philo-scientific method brings thoroughness, analysis, critique, speculation, evaluation, logic, 
ethics and metaphysics into the process of intellectual inquiry. It is only through this holistic approach that the complex nature of man can be explained with a high degree of certitude.

\section{References}

Aristotle, (1887) The Politics of Aristotle: With an Introduction, London: Claren press.

Aristotle-Metaphysics (1952) Translated by Richard Hope, New York: The University of Michigan Press.

Berry, C. J. (1986) Human Nature, London: MacMillan.

Blackburn, S. (1996) Oxford dictionary of Philosophy. New York: OxfordUniversity Press.

Delaney, J. (2006) Reusseaus and the Ethics of Virtue, London: Continuum International Publishing Group.

Dupre, J. (2001) Human Nature and the Limits of Science, Oxford: OxfordUniversity Press.

Ekanem, S. A (2005) "A Philosophy of Education for Technological Development in Nigeria", Unpublished Doctorate (Ph.D) Dissertation, University of Calabar, Calabar, Nigeria.

Ekanem, S. A. (2007) "Philosophy, Education, Science and Technology Defined" in Samuel A. Ekanem and Josseph N. Ogar

(Eds) Philosophy, Education, Science and Technology, Calabar: Samroi Publishers, Pp.1-26.

Ladgman, J. (2002) Understanding the Philosophy of Science, London: Routledge.

Ferguson, E. (2003) Background of Early Christianity, New York: B. Eerdmans Publishing.

Geras, N. (1983) Marx and Human Nature: Refutation of a Legend. London: Verso.

Habermas, J. (2003) The Future of Human Nature, Cambridge: Polity.

Ncha, G. B. (2008) "The Social Contractarians and the Development of the Society" in Samuel A. Ekanem and Joseph N. Ogar (Eds) A Systematic approach to Philosophy and Logic, Calabar: University of Calabar Press, Pp.160-181.

Omoregbe J. I. (2000) Ethics A Systematic and Historical Study, Lagos: Joja Press.

Omoregbe J. I (1996) Metaphysics Without Tears: A Systematic and Historical Study, Lagos: Joja Press.

Omoregbe J. I (2001) Philosophy of Mind: An Introduction to Philosophical Psychology, Lagos: Joja Press.

Ozumba, G. O. (2010) Philosophy and Method of Integrative Humanism, Calabar: Jochrisam Publishers.

Rousseau, J. (1968) The Social Contract, Translated by Maurice Cranston, New York: Penguin Classics.

Sarles, H. B. (1985) Language and Human Nature, Minnesota: University of Minnesota Press.

Stevenson, L. (1999) The Study of Human Nature, 2nd, Oxford: OxfordUniversity press.

Tanner, F. (1973) The Mystery Teachings in World Religions, Illinois: The Theosophical Publishing House.

Uduigwomen, A. F. and Maduka, E. (2007) "Philosophical Analysis/Survey of Science,Religionand Education".In Samuel A.

Ekanem and Joseph N. Ogar (Eds) Philosophy, Education, Science and Technology; Calabar: Samroi Publishers.

Wilson, E. O. (2004) On Human Nature, Harvard: HarvardUniversity Press.

Wikipedia, Free Encyclopedia "Human Nature", 17/7/2010. 
